\title{
ПРО ВИКОНАННЯ ПРОГРАМИ СПІЛЬНОЇ ДІЯЛЬНОСТІ МІНІСТЕРСТВА ОСВІТИ I НАУКИ УКРАЇНИ ТА НАЦІОНАЛЬНОЇ АКАДЕМІЇ ПЕДАГОГІЧНИХ НАУК УКРАЇНИ НА 2017-2020 РОКИ
}

Наукова доповідь на засіданні Президії НАПН України 18 листопада 2020 р.

https://doi.org/10.37472/2707-305X-2020-2-2-2-3

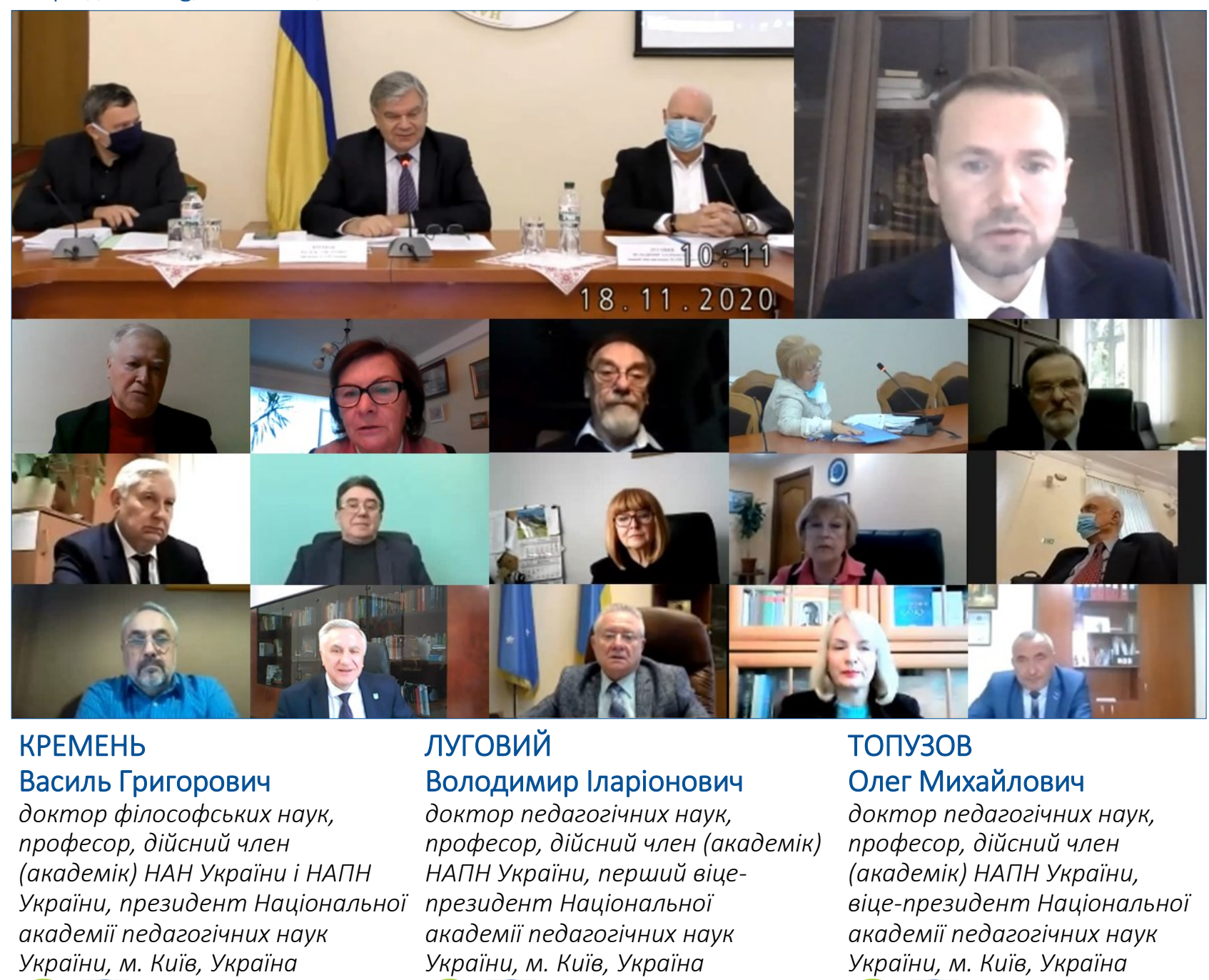

(iD)

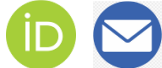

РЕГЕЙЛО Ірина Юріївна

доктор педагогічних наук, старший науковий співробітник, начальник науково-організаційного відділу апарату Президії Начіональної академії педагогічних наук України, м. Київ, Україна

(iD) $\bigcirc$
БАЗЕЛЮК Наталія Валеріївна кандидат педагогічних наук, заступник начальника науковоорганізаційного відділу апарату Президії Начіональної академії педагогічних наук України, м. Київ, Україна

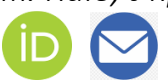


Анотація. Представлено інформацію про виконання Програми спільної діяльності МОН України та НАПН України на 2017-2020 роки, у межах якої здійснювалося удосконалення законодавства України та розроблення концептуальних і нормативних документів у срері освіти; науково-методичний супровід експериментів всеукраїнського рівня; підготовка навчально-методичного забезпечення для Нової української школи, зокрема для дітей з особливими потребами; психолого-педагогічна експертиза навчальної, навчально-методичної літератури, засобів навчання та навчального обладнання; підвищення кваліфікації керівних, науковопедагогічних і педагогічних прачівників; участь у роботі експертних, робочих груп, конкурсних комісій МОН України; проведення спільних науково-практичних масових заходів тощо. Окреслено питання, що потребують подальшого вирішення в рамках спільної діяльності стосовно усіх ланок освіти: дошкільної, початкової, базової і профільної середньої, позашкільної освіти, освіти дітей з особливими потребами, професійної (професійно-технічної), фахової передвищої, вищої освіти та освіти дорослих.

Ключові слова: Програма спільної діяльності; Міністерство освіти і науки України; Національна академія педагогічних наук України; наука; освіта; педагогіка; психологія; науковий і методичний супровід освіти; розвиток інноваційної людини.

Об'єднання зусиль фахівців Міністерства освіти і науки України та вчених Національної академії педагогічних наук України відкриває нові можливості в теоретико-методологічному, науково-методичному та інформаційному супроводі розвитку сучасної освіти, сприяє ефективному розв'язанню актуальних проблем, що постали перед національною системою освіти в нових умовах розвитку українського суспільства в контексті європейської інтеграції і світової глобалізації.

Реалізація Програми спільної діяльності МОН України та НАПН України на 2017-2020 роки (далі - Програма) передбачала виконання

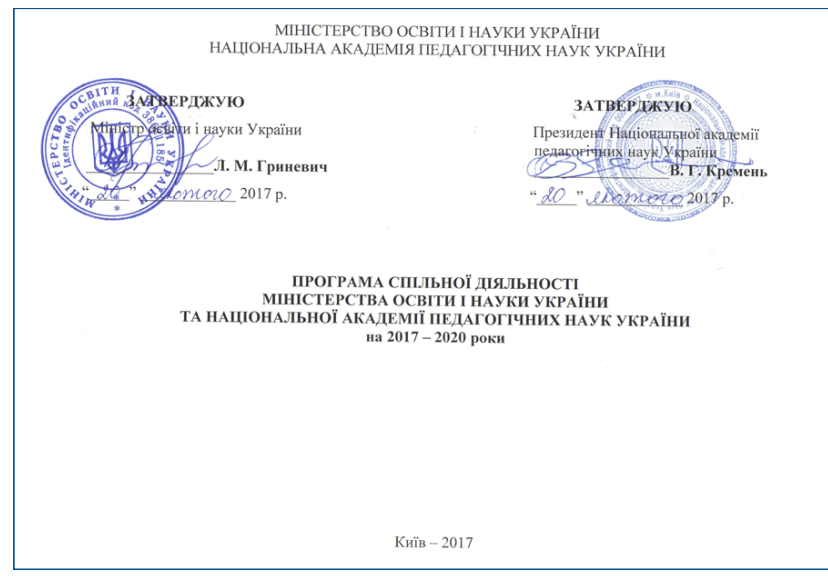

115 заходів, спрямованих на вирішення нагальних завдань з реформування вітчизняної освіти, за такими десятьма напрямами: «Загальні проблеми розвитку освітнього простору», «Дошкільна та загальна середня освіта», «Позашкільна освіта і виховна робота», «Професійна (професійнотехнічна) освіта», «Вища освіта», «Педагогічна освіта і освіта дорослих», «Психологічний супровід освіти», «Управління освітньою та науковою діяльністю, інформаційне забезпечення освіти», «Міжнародне співробітництво» та «Проведення спільних науково-практичних масових заходів».

Питання про виконання Програми щороку заслуховувалися на засіданнях Президії НАПН
України (постанови Президії НАПН України від 15 листопада 2017 р. № 1-2/14-341, від 14 листопада 2018 р. № 1-2/13-328, від 14 листопада 2019 р. № 1-2/10-313).

3-поміж загальних проблем розвитку освітнього простору одним із пріоритетних завдань було удосконалення законодавства України у сфері освіти. Вчені НАПН України спільно з фахівцями МОН України працювали над підготовкою проєктів законів України «Про освіту» (прийнято 5 вересня 2017 р. № 2145-VIII), «Про повну загальну середню освіту» (прийнято 16 січня 2020 р. № 463-IX), «Про фахову передвищу освіту» (прийнято 6 червня 2019 р. № 2745-VIII), «Про професійну (професійно-технічну) освіту», «Про внесення змін до Закону України «Про позашкільну освіту», «Про внесення змін до деяких законодавчих актів України щодо вдосконалення освітньої діяльності у сфері вищої освіти», «Про освіту дорослих» тощо.

Здійснювалося розроблення концептуальних та нормативних документів у галузі освіти. Вчені НАПН України взяли участь у розробленні пропозицій до проєктів: державних стандартів (Державний стандарт початкової освіти, Державний стандарт базової середньої освіти, оновлений Базовий компонент дошкільної освіти, Стандарт спеціалізованої освіти наукового спрямування тощо), стратегій (Стратегія розвитку вищої освіти України на 2021-2031 роки, Стратегія
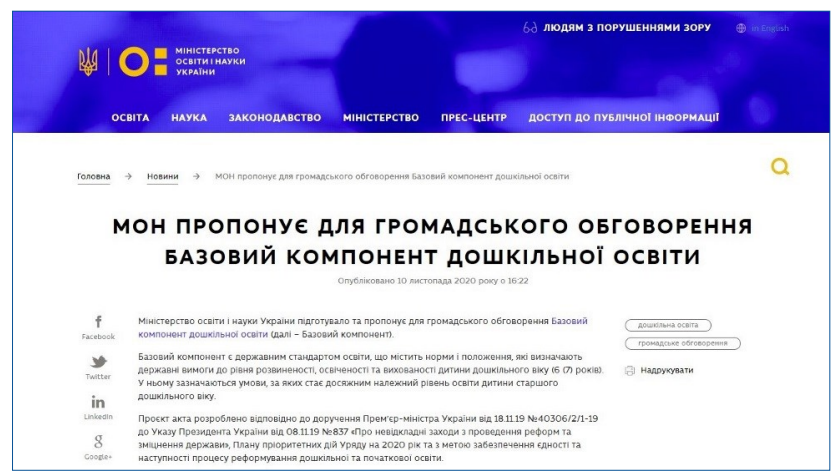
розвитку професійної (професійно-технічної) освіти на період до 2023 року, Стратегія розвитку громадянської освіти на період до 2030 року тощо), постанов та розпоряджень Кабінету Міністрів України, наказів МОН України, навчальних програм, професійних стандартів та ін.

Зокрема, у 2020 р. від НАПН України подавалися пропозиції до Положення про центр професійного розвитку педагогічних працівників, Положення про конкурсні відбори наукових, науковотехнічних робіт та проєктів, які фінансуються за рахунок зовнішнього інструменту допомоги Європейського Союзу для виконання зобов'язань України у Рамковій програмі Європейського Союзу з наукових досліджень та інновацій «Горизонт 2020», Порядку визнання в Україні професійних кваліфікацій, здобутих в інших країнах, Порядку проведення іспиту на рівень володіння державною мовою, Форми сертифіката про акредитацію освітньої програми, порядку оформлення, переоформлення, видачі, зберігання та обліку таких сертифікатів, Переліку спеціальностей, за якими проводиться єдиний державний кваліфікаційний іспит для здобуття ступеня магістра, Концепції реалізації державної політики розвитку українських е-інфраструктур до 2023 року та затвердження Плану заходів щодо ії реалізації, Концепції державної програми розвитку дослідницьких інфраструктур в Україні до 2026 року, Плану заходів щодо популяризації природничих наук та математики, Плану заходів щодо реалізації Концепції розвитку природничо-математичної освіти (STEM-освіти) на 2020-2027 роки, Положення про дистанційну форму здобуття загальної середньої освіти, Примірного положення про психолого-педагогічний консиліум, Умов допуску асистента учня до освітнього процесу та вимоги до нього, Порядку проведення експертизи та затвердження освітніх програм повної загальної середньої освіти, розроблених не на основі типових освітніх програм, Порядку підготовки та допуску до освітньої діяльності в системі освіти пластових виховників та скаутлідерів за пластовою, скаутською освітньою (навчальною) програмою чи пластовим або скаутським методом, Умов прийому на навчання для здобуття вищої освіти в 2021 році тощо; нових редакцій Порядку забезпечення підручниками та посібниками здобувачів повної загальної середньої освіти і педагогічних працівників, Ліцензійних умов провадження освітньої діяльності, Порядку визнання здобутих в іноземних закладах вищої освіти ступенів вищої освіти, Порядку визнання в Україні документів про середню, середню професійну, професійну освіту, виданих закладами освіти інших держав тощо; внесення змін до Національної рамки кваліфікацій, Порядку розміщення державного замовлення на підготовку фахівців, наукових, науково-педагогічних та робітничих кадрів, підвищення кваліфікації та перепідготовку кадрів, Критеріїв оцінювання навчальних досягнень учнів (вихованців) у системі загальної середньої освіти, Порядку формування Переліку наукових фахових видань України тощо; навчальних програм 3 предмету «Захист України» для 10-11 класів закладів спеціалізованої освіти військового профілю та для 10-11 класів закладів загальної середньої освіти (рівень стандарту); професійних стандартів на посади «Асистент», «Викладач», «Старший викладач», «Доцент», «Професор», за професіями «Вчитель початкових класів закладу загальної середньої освіти», «Вчитель закладу загальної середньої освіти», «Практичний психолог» й інших (МОН України, 2020а).

За пріоритетним напрямом «Дошкільна ma загальна середня освіта» співпраця вчених Інституту педагогіки НАПН України з фахівцями $\mathrm{MOH}$ України спрямовувалася на реалізацію Плану заходів на 2017-2029 роки із запровадження Концепції реалізації державної політики у сфері реформування загальної середньої освіти «Нова українська школа». Здійснювалися науковометодичний супровід 20 експериментів всеукраїнського рівня, підготовка навчально-методичного забезпечення освітнього процесу у закладах загальної середньої освіти (підготовлено 73 підручники, понад 100 навчально-методичних посіб-

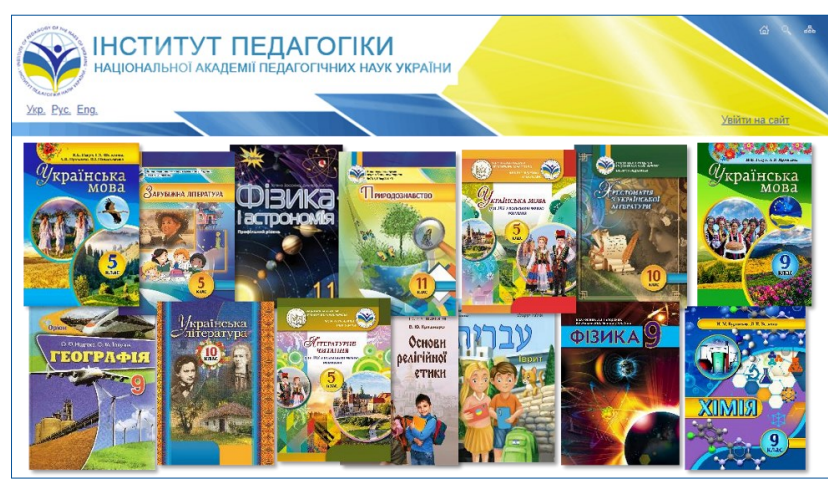

ників). Щороку надавалися методичні рекомендації й проводилися серпневі конференції щодо викладання навчальних предметів у закладах загальної середньої освіти. Здійснювався організаційно-методичний супровід підвищення кваліфікації й сертифікації учителів початкової школи 
для роботи за новим стандартом, розроблення нової системи вимірювання й оцінювання результатів навчання учнів. У 2020 р. підготовлено 10 підручників для 3 класу, понад 20 навчальнометодичних посібників, збірник методичних рекомендацій для вчителів 3-х класів Нової української школи; проводився ряд заходів із науковометодичного супроводу освітнього процесу в умовах карантину, зокрема участь у проєкті МОH України «Всеукраїнська школа онлайн», розроблення та розміщення в мережі Інтернет навчальних і методичних матеріалів для дистанційного й змішаного навчання.

Вчені Інституту проблем виховання НАПН України працювали над експериментальним упровадженням Програми «Нова українська школа у поступі до цінностей», що реалізується у співпраці з ДНУ «Інститут модернізації змісту освіти» МОН України. Імплементація положень та принципів Програми відбувається на базі закладів загальної середньої освіти Донецької, Київської, Кіровоградської, Миколаївської, Одеської, Рівненської, Тернопільської, Хмельницької, Черкаської областей.

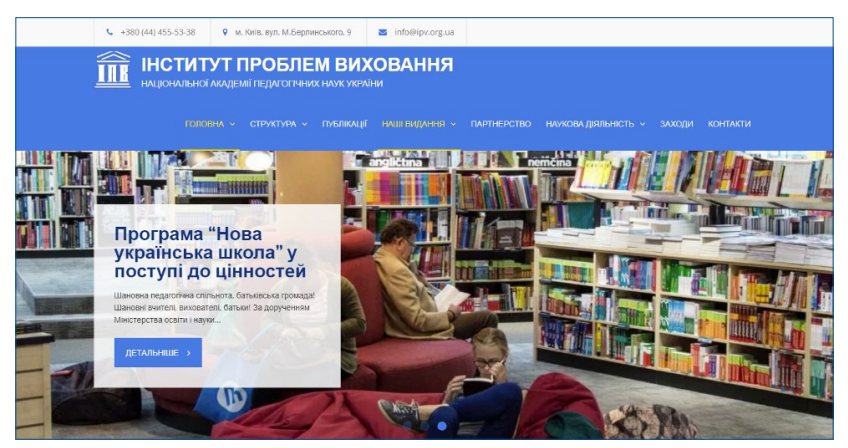

Наукове керівництво та науково-методичний супровід експериментів всеукраїнського рівня «Розвиток інклюзивного освітнього середовища у Запорізькій області», «Удосконалення процесу опанування навичок читання шляхом упровадження адаптивного кириличного шрифту Inclusion UKR y навчально-виховний процес учнів 12 класів закладів загальної середньої освіти», проєкту «Розроблення науково-методичного забезпечення для інклюзивно-ресурсних центрів» за підтримки представництва Дитячого фонду ООН (ЮНІСЕФ) в Україні здійснювали вчені Інституту спеціальної педагогіки і психології імені Миколи Ярмаченка НАПН України. Розпочато імплементацію моделі стандартизації навчальнометодичного забезпечення навчання молодших школярів з тяжкими порушеннями мовлення, Типового навчального плану спеціальних закла-

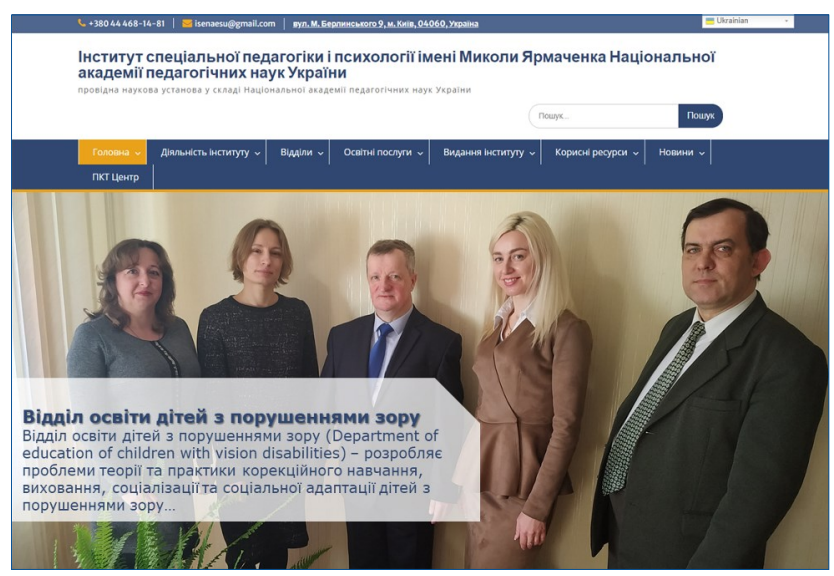

дів загальної середньої освіти для дітей з тяжкими порушеннями мовлення тощо. Здійснювалося розроблення наукового, програмного та навчально-методичного забезпечення освіти дітей $з$ особливими потребами та проведення курсів підвищення кваліфікації педагогічних працівників, зокрема у дистанційному режимі.

Інноваційною роботою вчених Інституту інформаційних технологій і засобів навчання НАПН України за звітний період охоплено понад 160 закладів загальної середньої освіти та 35 закладів вищої освіти, зокрема розширено мережу спільних науково-дослідних лабораторій з проблем використання ІКТ. Всеукраїнський рівень упровадження результатів дослідноекспериментальної роботи отримали спільні проєкти інституту і МОН України - «Хмарні сервіси в освіті», «Розумники», «Технологія навчання учнів початкової школи «Розумники» (Smart Kids)», «Варіативні моделі комп'ютерно орієнтованого середовища навчання предметів природничо-математичного циклу в загальноосвітньому навчальному закладі». Підвищено цифрову компетентність учителів за напрямами: «Цифрова компетентність вчителя Нової української школи» (56 вчителів, спеціалістів системи післядипломної педагогічної освіти, керівників закладів загальної середньої освіти); використання електронних освітніх ресурсів у межах всеукраїнсь-

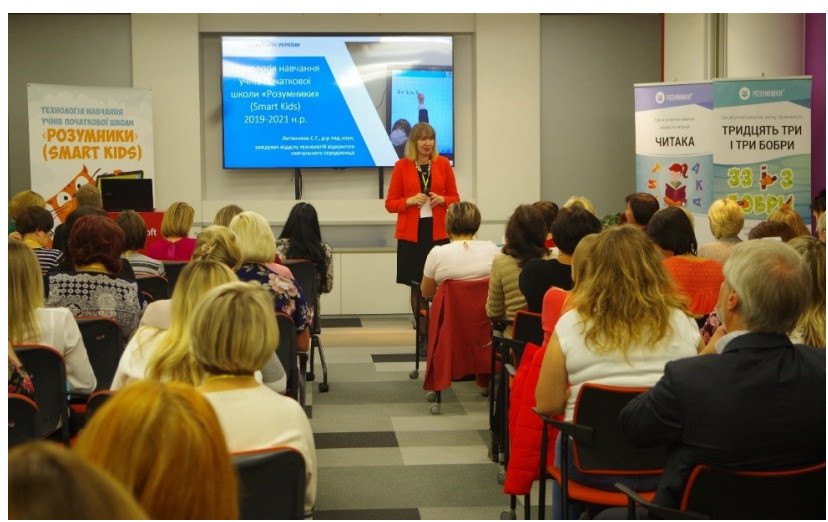


кого експерименту «Технологія навчання учнів початкової школи «Розумники» (SmartKids)» (210 учителів початкових класів закладів загальної середньої освіти). Протягом 2018-2019 рр. інститут взяв участь у Міжнародному проєкті «V4+ Academic Research Consortium integrating data bases, robotic sand languages technologies» (V4+ Академічний Дослідницький Консорціум з інтеграції баз даних, робототехніки та мовних технологій) за підтримки міжнародного Вишеградського фонду.

у 2020 р. Інститутом розроблено методичні рекомендації щодо використання комп'ютерного моделювання для формування компетентностей учнів з природничо-математичних предметів; методичний посібник з питань використання сервісів адаптивних хмаро орієнтованих систем у майбутній професійні діяльності вчителів; методичний посібник й методичні рекомендації щодо застосування електронних науково-освітніх систем для розвитку інформаційно-дослідницької компетентності наукових, науково-педагогічних працівників та аспірантів. Здійснювався науковометодичний супровід формування ІК-компетентності вчителів в умовах хмаро орієнтованого навчального середовища шляхом проведення тренінгів, семінарів, випуску електронного ресурсу «ннформаційний бюлетень» $з$ питань використання засобів хмаро орієнтованого навчального середовища для розвитку ІК-компетентності вчителів.

Вченими Інституту обдарованої дитини НАПН України спільно з Національним центром «Мала академія наук України» створено і забезпечується функціонування Всеукраїнського науково-методичного віртуального STEM-центру. Розроблено

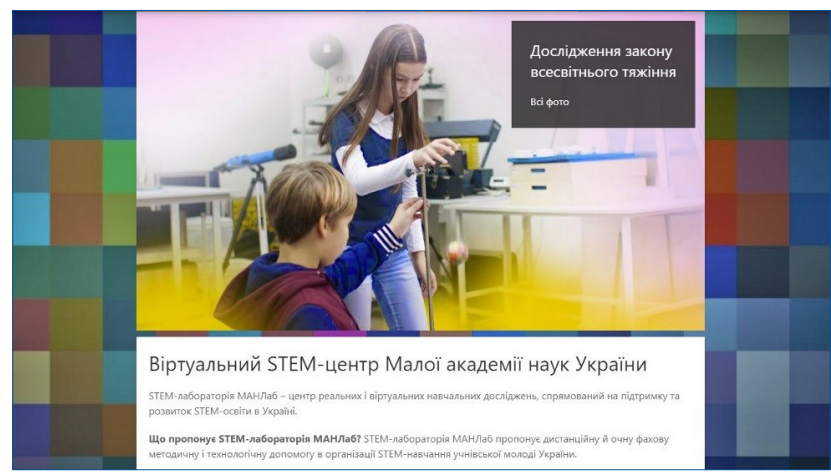

та впроваджено комп'ютеризовану комплексну профорієнтаційну програму для старшокласників, яка провадить діагностику інтересів, здібностей, цінностей за методикою професійної спрямованості Дж. Холланда; особистісних особливостей, характеру за опитувальником Р. Кеттела. Щорічно проводилися відбір і спеціальна підготовка обдарованих учнів до участі у щорічній Міжнародній конференції молодих учених «ICYS». У 2020 р. надавалася інформаційна та методична підтримка проведення Всеукраїнського STEM-тижня (27 квітня - 30 квітня 2020 р.).

За пріоритетним напрямом «Профресійна (профресійно-технічна) освіта» в Інституті професійно-технічної освіти НАПН України розроблено, обґрунтовано та впроваджено: 4 концепції, 2 моделі, 3 методичні системи, 11 методик, 5 технологій. Підготовлено й опубліковано 23 праці (навчальна продукція з грифами МOH України - 4, наукова - 6, виробничо-практична 10, довідкова - 2). Здійснювався науковометодичний супровід експериментів всеукраїнсь-

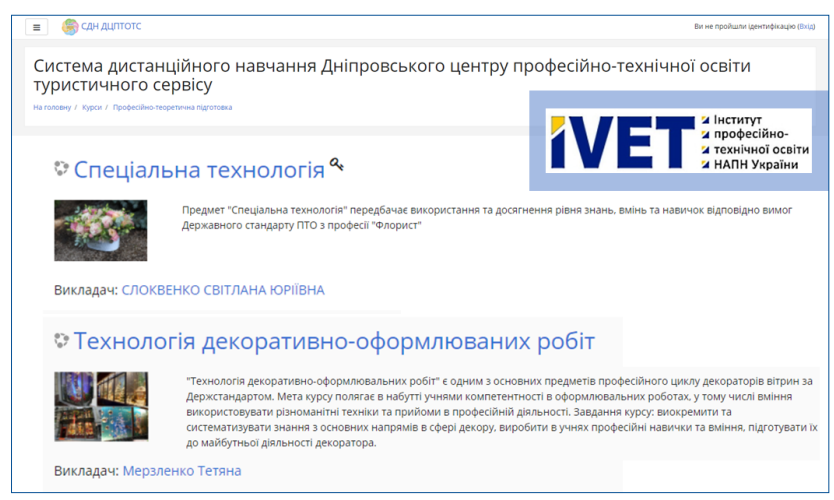

кого рівня. У 2020 р., зокрема, підготовлено підручник «Сучасні технології кондитерського виробництва»; опубліковано комплект навчальнометодичного забезпечення 3 дистанційного навчання; розроблено методику організації дуальної форми навчання у закладах професійної (професійно-технічної) освіти для професійної підготовки майбутніх кваліфікованих робітників будівельної, машинобудівної галузей, сфери обслуговування та громадського харчування; технологію розвитку соціального партнерства в закладах професійної (професійно-технічної) освіти в умовах дуальної форми навчання; модель взаємодії закладів професійної (професійнотехнічної) освіти з соціальними партнерами 3 використанням технологій стратегічного менеджменту. Вчені інституту брали участь у проєктах програми ЄС Еразмус+: «Удосконалення практикоорієнтованої підготовки викладачів професійної освіти і навчання», ITE-VET (2016-2018 рр.); «Нові механізми управління на основі партнерства та стандартизації підготовки викладачів професійної освіти в Україні», PAGOSTE (2020-2023 рр.).

Відповідно до пріоритетного напряму «Вища освіта» вченими Інституту вищої освіти НАПН 
України проведено тренінги для формування мережі експертів із забезпечення якості вищої освіти, за результатами яких підготовлено 46 тренерів 3 міжнародною сертифікацією та 1272 експерти для закладів вищої освіти.

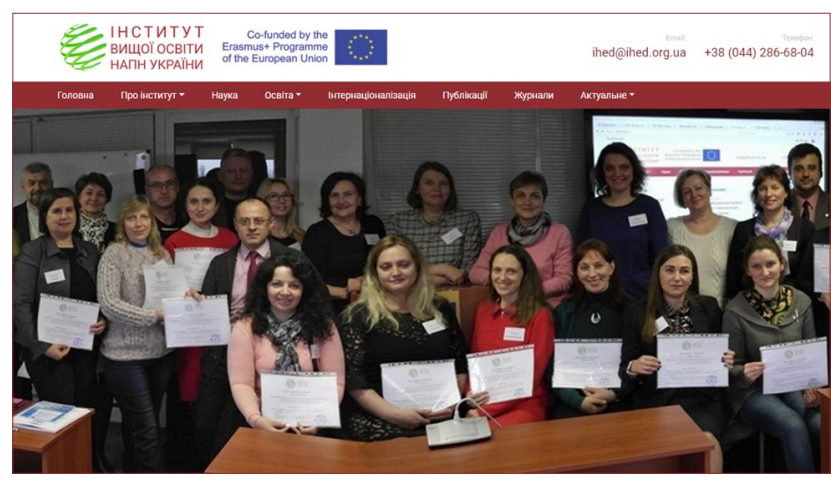

У рамках Проєкту ЄС Еразмус+ «Імплементація системи забезпечення якості освіти через співпрацю Університет - Бізнес - Уряд у закладах вищої освіти», EDUQAS апробовано механізм оцінювання внутрішніх систем забезпечення якості закладів вищої освіти, розроблено звіт та рекомендації для самооцінювання університетів у процесі проходження акредитаційних процедур. Проведено тренінги для членів науковометодичних комісій Міністерства освіти і науки України (731 особа); загальнонаціональне опитування з метою визначення пріоритетів і потреб розвитку університетів України у процесі реформування вищої освіти у контексті європейської інтеграції; Міжнародний семінар (спільно з Еразмус+) «Процедури, інструменти, критерії, системи забезпечення якості вищої освіти»; круглий стіл за участі провідних ректорів закладів вищої освіти України «Нова модель економічної діяльності у сфері вищої освіти України» тощо. Здійснено інституційний аудит переміщених університетів у межах Проєкту ЄС «Відродження переміщених університетів: посилення конкурентоспроможності, підтримка громад» / «Reinventing displaced universities: enhancing competitiveness, serving communities», REDU (2020-2023 рр.), вартістю 1,5 млн €.

За пріоритетним напрямом «Педагогічна освіma і освіта дорослих» учені Інституту педагогічної освіти і освіти дорослих імені Івана Зязюна НАПН України взяли участь у підготовці Регіонального звіту щодо розвитку освіти дорослих для Глобального звіту з освіти і навчання дорослих ЮНЕСКО (у контексті виконання Рекомендацій міжнародної Конференції ЮНЕСКО CONFINTEA VI м. Білем, 2009). Інститут разом з Університетом Аугсбургу (Німеччина), Чернівецьким національ- ним університетом імені Юрія Федьковича долучився до спільного німецько-українського науково-дослідного проєкту «На шляху до запровадження наукової галузі «Освіта дорослих і неперервна освіта» в Україні» (2016-2018 рр.), став учасником міжнародної програми CiSEP (Civic School for Sound EU Practice) у сфері освіти дорослих 3 проєктного менеджменту європейських грантів (EU Project Cycle). Для МOH України підготовлено інформаційно-аналітичні матеріали за результатами дослідження систем безперервної педагогічної освіти зарубіжних країн «Зарубіжний досвід професійної підготовки педагогів». 3 метою вдосконалення змісту професійної підготовки вчителів у закладах вищої та післядипломної педагогічної освіти розроблено і впроваджуються: науково-методичний комплекс «якість педагогічної освіти України» для педагогічних, науково-педагогічних працівників, керівників освітньої галузі; науково-методичні матеріали щодо неформальної освіти різних категорій дорослих; навчально-методичні матеріали щодо організації підвищення кваліфікації різних категорій педагогічних працівників на основі зарубіжного досвіду; навчально-методичний комплекс «Професійна орієнтація у Новій українській школі» для слухачів курсів підвищення кваліфікації (стажування). Організовано й проведено 46 спільних науково-практичних масових заходів із закладами освіти. Розроблено та оприлюднено відеоролики щодо можливостей самореалізації і психологічної підтримки окремих категорій дорослих в умовах карантину.

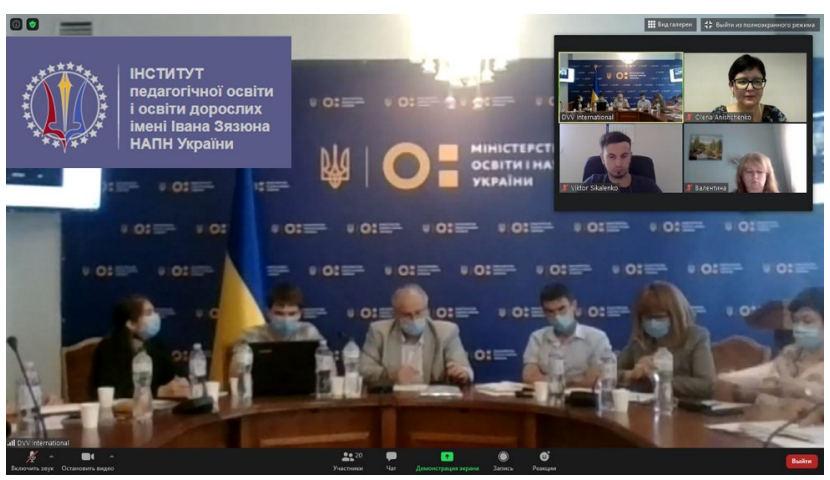

Здійснювалося науково-методичне консультування, науково-методична підтримка з питань професійного розвитку і саморозвитку вчителя, удосконалення психолого-педагогічної взаємодії, розвитку освіти дорослих у спільних науковометодичних лабораторіях інституту і закладів вищої освіти (Харківського національного педагогічного університету імені Г.С. Сковороди; Жито- 
мирського державного університету імені Івана Франка; Вінницького державного педагогічного університету імені Михайла Коцюбинського); функціонував Центр освіти дорослих інституту, зокрема його підструктури: Центр підвищення кваліфікації для наукових, науково-педагогічних, педагогічних працівників; Психологічний консультативно-тренінговий центр для надання психологічної допомоги вчителям, науковим, науковопедагогічним працівникам; Центр педагогічної майстерності; Дистанційна школа демократії та громадянського суспільства.

Науково-педагогічними працівниками ДзВО «Університет менеджменту освіти» розроблено й упроваджено в освітній процес комплекс методичних та організаційних засобів для вивчення громадської думки щодо освітніх послуг університету в онлайн та офлайн режимах. Здійснювалося наукове керівництво дослідно-експериментальною роботою «Управління розвитком закладів професійної (професійно-технічної) освіти на засадах педагогічної логістики» (2019-2023рр.). У 2019 2020 рр. організовано роботу з безперервного професійного розвитку фахівців на базі освітньої платформи Білоцерківського інституту неперервної професійної освіти університету «Профосвіта». Ефективно функціонує Віртуальна школа педагогічного коучингу.

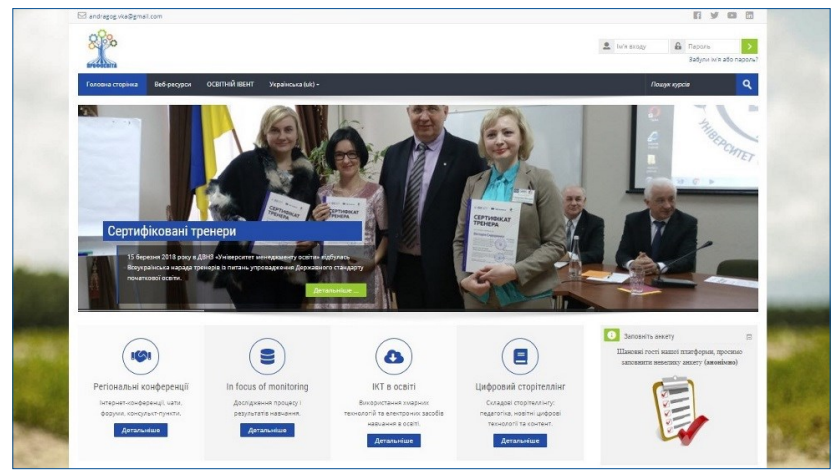

Тривала співпраця вчених НАПН України 3 працівниками МОН України щодо психологічного супроводу освіти. Зокрема, вчені Інституту психології імені Г.С. Костюка НАПН України впроваджували в освітню практику п'ять практично орієнтованих монографій, посібник і методичні рекомендації. Успішно завершено два експерименти всеукраїнського рівня: «Психологічні засади інноваційних технологій розвитку особистості» (20152019 рр.) та «Психолого-педагогічні засоби оцінки рівня сформованості компетентностей молодших школярів як чинник управління якістю навчання в системі розвивальної освіти» (2014-
2018 рр.). У ході виконання експерименту всеукраїнського рівня «Психолого-педагогічні умови становлення ціннісних орієнтацій дітей в ігровій та навчальній діяльності освітньої системи «Радість розвитку» (2015-2025 рр.) здійснювалося системне впровадження комплексної програми особистісного розвитку дитини. Проведено низку навчальних семінарів та установчих нарад для педагогічних колективів експериментальних закладів.

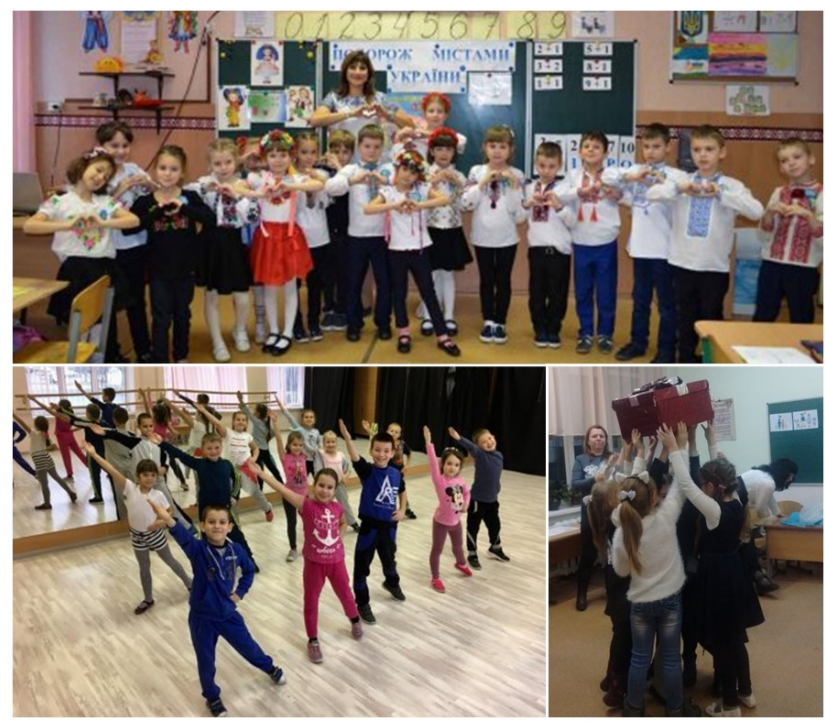

Вченими Інституту соціальної та політичної психології НАПН України розроблено і впроваджено на всеукраїнському рівні концепцію формування в громадській думці позитивного образу освітніх інновацій, організаційні форми та методичні засоби соціально-психологічного супроводу впровадження освітніх реформ. Розроблено психолого-педагогічні технології формування позитивної громадської думки стосовно освітніх реформ, зокрема технології розбудови партнерської взаємодії в освіті, визначено їх роль у формуванні позитивної громадської думки щодо реформи в освіті, запропоновано технології запобігання і вирішення конфліктів. Розроблено соціально-психологічну теорію відновлення психологічного здоров'я особистості, побудовану на її основі концепцію соціально-психологічної реабілітації особистості, моделі і психореабілітаційні технології самодопомоги і сприяння посттравматичному зростанню. Створено концептуальну модель і стратегії адаптації спільноти до суспільних змін унаслідок воєнного конфлікту, визначено шляхи і засоби запобігання негативним психологічним наслідкам воєнних дій. Запропоновано стратегії та технології активізації самоідентифікування молоді, визначено механізми громадянської і національної самоідентифікації. 
Створено програму для учнів 9-10-х класів «Медіакультура», медіаосвітні модулі дистанційних курсів для платформи Prometheus: «Медіаграмотність: практичні навички», «Медіаграмотність для освітян», «Протидія булінгу в закладах освіти».

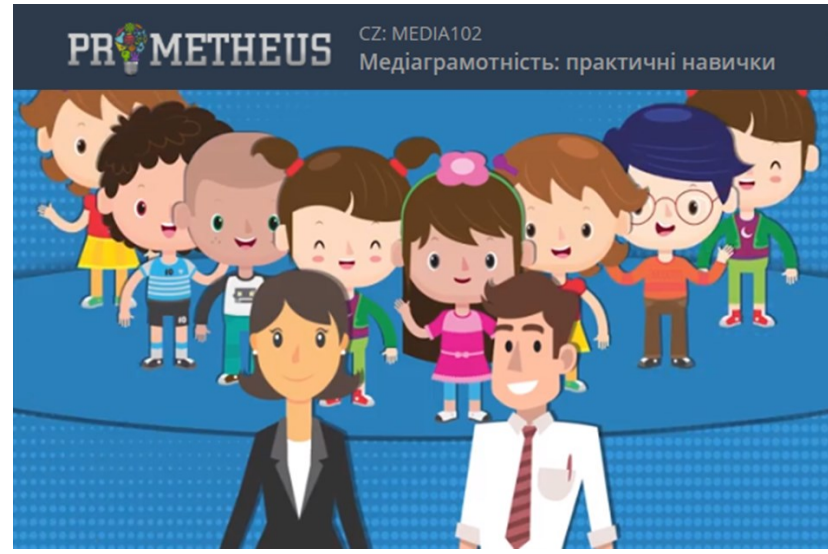

у 2020 р. в інституті розроблено дослідницькі методики «Освіта в умовах COVID-19», «Психологічні наслідки пандемії COVID-19», «Роботи/штучний інтелект в житті дитини», «Емоційний аспект ставлення педагогічної спільноти до різних напрямів реформування загальної середньої освіти». Реалізовано відкритий проєкт психологічної допомоги під час пандеміїі COVID19 «Онлайн-коло», у рамках якого проведено 90 заходів за участі понад 300 тис. осіб. Проведено тематичні заняття з організації освітнього процесу онлайн; групи підтримки та інтервізійні групи для психологів системи освіти і освітян; цикл відеолекцій «Медіагігієна під час пандемії Covid-19»; заняття з регуляції психоемоційних станів; розроблено інформаційно-методичні матеріали (інфографіка) для психологів системи освіти.

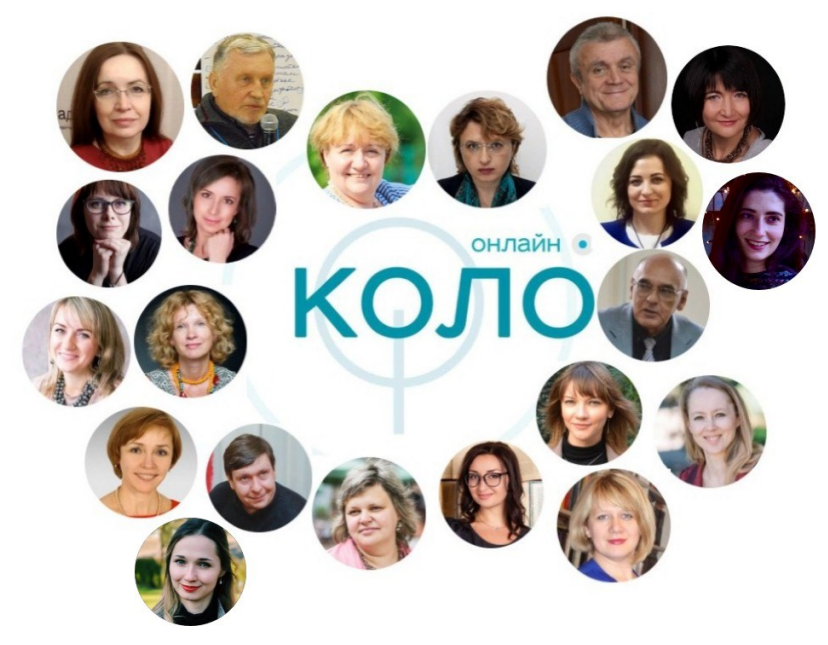

Наукові працівники Українського науковометодичного центру практичної психології і соціальної роботи у 2018 р. та у 2020 р. провели два етапи всеукраїнського моніторингового дослідження серед учасників освітнього процесу «Надання допомоги постраждалим від військових дій і внутрішньо переселеним особам в діяльності психологічної служби»; видали методичні матеріали для працівників психологічної служби; розробили Положення про психологічну службу у системі освіти України (2018р.), типову документацію працівників психологічної служби у системі освіти України (2019р.); проєкт Концепції психологічного супроводу освітніх реформ в діяльності психологічної служби у системі освіти (2020 р.).

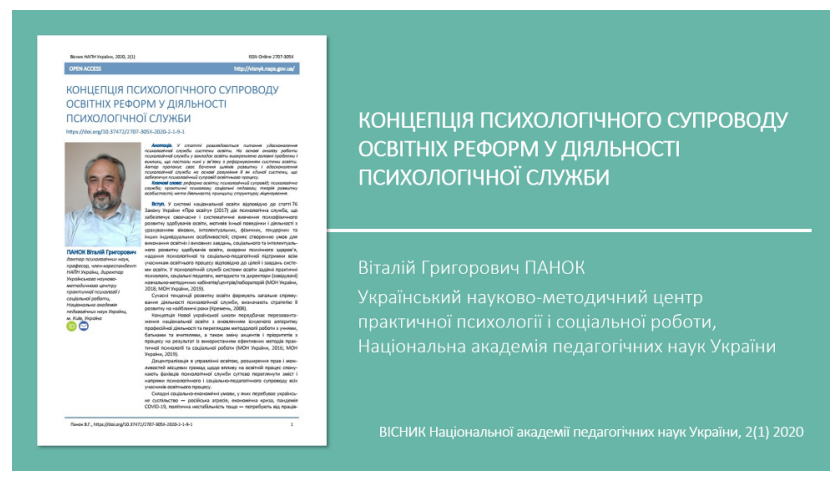

За пріоритетним напрямом «Управління освітньою та науковою діяльністю, інформаційне забезпечення освіти» вчені НАПН України брали активну участь у роботі Акредитаційної комісії України, Наукової ради, Науково-методичної ради (ї̈ науково-методичних комісій / підкомісій), Експертної ради з питань проведення експертизи дисертацій, робочих груп при МОН України (Робоча група супроводу Болонського процесу в Україні, Громадська рада при МОН України, Рада 3 національно-патріотичного виховання дітей та молоді при МОН України, Рада представників громадських об'єднань корінних народів, національних меншин України при МОН України та ін.), експертних, робочих груп, конкурсних комісій МОН України. Зокрема, вчені підвідомчих установ НАПН України проводили психолого-педагогічну експертизу навчальної, навчально-методичної літератури, засобів навчання та навчального обладнання для закладів дошкільної, початкової, середньої (у т.ч. для дітей з особливим освітніми потребами), позашкільної, професійної (професійно-технічної) освіти тощо, засобів навчання і навчального обладнання для надання грифів і свідоцтв МОН України. 
Вчені НАПН України виступали у якості членів редакційних колегій та рад, рецензентів та авторів наукових періодичних видань, засновниками яких $€$ наукові установи та заклади вищої освіти МOH України. Близько 20 наукових періодичних видань засновані підвідомчими установами НАПН України спільно із закладами вищої освіти МOH України, зокрема Запорізьким національним університетом, Кам'янець-Подільським національним університетом імені Івана Огієнка, Національним педагогічним університетом імені М.П. Драгоманова, Національним технічним університетом «Харківський політехнічний інститут», ПЗВО «Арт академія сучасного мистецтва імені Сальвадора Далі», ПЗВО «Київський міжнародний університет», Полтавським національним педагогічним університетом імені В.Г. Короленка, Східноєвропейським національним університетом імені Лесі Українки, Уманським державним педагогічним університетом імені Павла Тичини, Харківським національним університетом міського господарства імені О.М. Бекетова, Херсонським державним університетом, Хмельницькою гуманітарно-педагогічною академією, Хмельницьким національним університетом та ін.

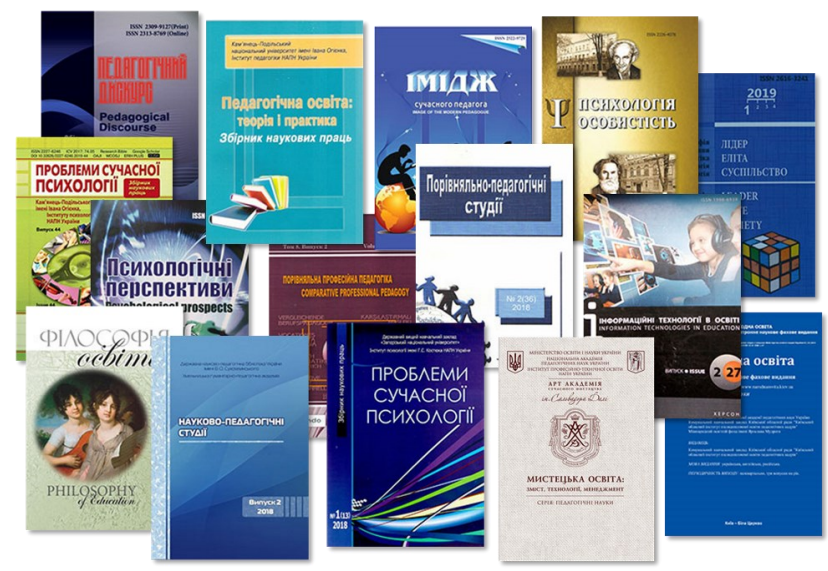

Співпраця наукових працівників підвідомчих установ НАПН України та наукового-педагогічних працівників закладів вищої освіти здійснювалася у ході консультаційної діяльності Міжвідомчої ради з координації досліджень у галузі освіти, педагогіки і психології, до складу якої входять 82 провідних вчених України. Протягом $2017-$ 2020 рр. Міжвідомчою радою розглянуто понад 2 тис. тем дисертаційних робіт, з яких 48 \% узгоджено та скоординовано.

Важливим внеском у процес цифровізації освіти і науки України, сприяння поширенню наукових результатів та поінформованості громадськості про розробки НАПН України є функціонуван- ня і постійне поповнення інформаційних ресурсів Електронної бібліотеки НАПН України, в якій представлено понад 22 тис. ресурсів вчених академії, що завантажено понад 7 млн разів.

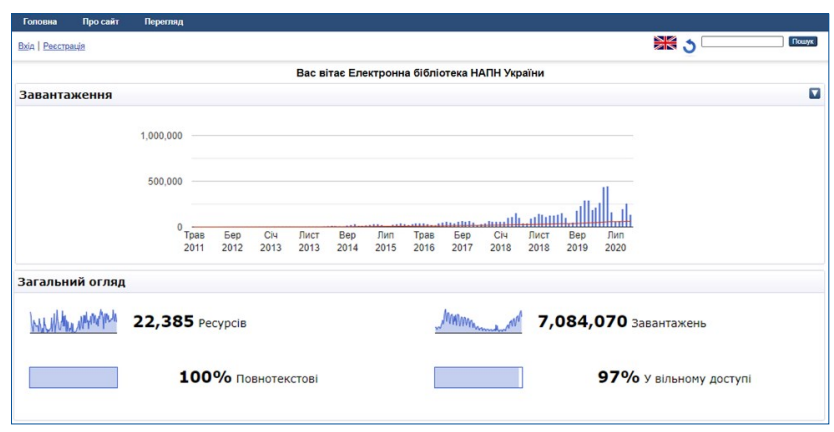

Державною науково-педагогічною бібліотекою України імені В.О. Сухомлинського спільно з ДНУ «Інститут модернізації змісту освіти» у межах виконання Програми проводилися: міжнародна науково-практична конференція та всеукраїнські педагогічні читання «Василь Сухомлинський у діалозі з сучасністю», щорічні всеукраїнські місячники шкільних бібліотек, всеукраїнський конкурс «Шкільна бібліотека», дистанційний флешсемінар «Імідж бібліотекаря в освітньому просторі: злам стереотипів» у рамках XI Львівського міжнародного бібліотечного форуму тощо. Здійснювалася консультаційно-методична діяльність щодо упровадження УДК в практику роботи освітянських бібліотек. Функціонує система підготовки науково-інформаційних матеріалів та електронних ресурсів із метою здійснення науковоінформаційного супроводу освіти: формується електронний каталог та Науково-педагогічна електронна бібліотека, електронний ресурс «Бібліотека Нової української школи», здійснюється експозиційно-виставкова діяльність, підготовлено наукову, навчальну, виробничо-практичну довідкову, інформаційно-аналітичну, реферативну та бібліографічну продукцію з актуальних питань інноваційного розвитку національної освіти. У 2020 р., зокрема, підготовлено й оприлюднено на вебпорталі рекомендаційні бібліог-
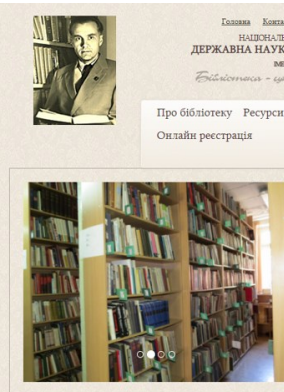

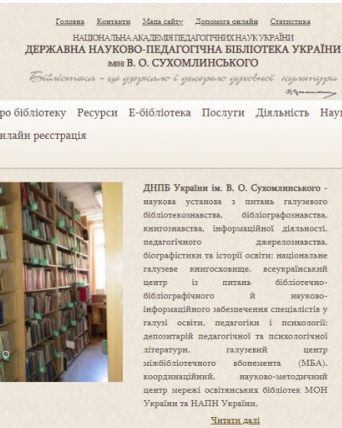

4imantinis

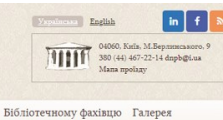

Наша анкета

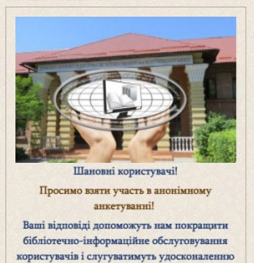


рафічні списки на допомогу науковопедагогічним працівникам «Дистанційне навчання як важливий складник сучасної освіти», «Законодавче та нормативно-правове забезпечення сфери освіти України для протидії поширенню COVID-19», «Коронавірус COVID-19», розроблено рекомендації щодо виходу освітянських бібліотек із карантину, спричиненого COVID-19.

Особливе місце у виконанні заходів Програми відведено проведенню спільних з МОН України науково-практичних масових заходів - конференцій, семінарів, круглих столів, освітянських виставок, організації різноманітних конкурсів, олімпіад тощо. Протягом терміну дії Програми проведено 15 міжнародних спеціалізованих виставок, з них три у 2020 р.: «Сучасні заклади освіти - 2020», «ннноватика в сучасній освіті 2020», «Освіта та кар'єра - 2020». У ході роботи зазначених виставок 2020 р. установи НАПН України організували та провели 60 заходів за участі науковців, освітян-практиків, працівників органів управління освітою різних рівнів, зацікавленої громадськості. Вчені НАПН України взяли участь у конкурсах, що проводились організаторами виставок. За їх підсумками наукові колективи установ академії нагороджено 26 золотими медалями виставок. Почесними нагородами «Національне визнання наукових досягнень» Міжнародної спеціалізованої виставки «Інноватика в сучасній освіті - 2020» відзначено розробки Інституту педагогіки НАПН України, Інституту спеціальної педагогіки і психології імені Миколи Ярмаченка НАПН України, Інституту соціальної та політичної психології НАПН України, Інституту професійно-технічної освіти НАПН України. Гранпрі «Лідер післядипломної освіти України» Міжнародної спеціалізованої виставки «Інноватика в сучасній освіті - 2020» отримав ДЗВО «Університет менеджменту освіти». Університет також відзначено дипломом «Лідер післядипломної освіти України» Міжнародної спеціалізованої виставки «Освіта та кар'єра - 2020».

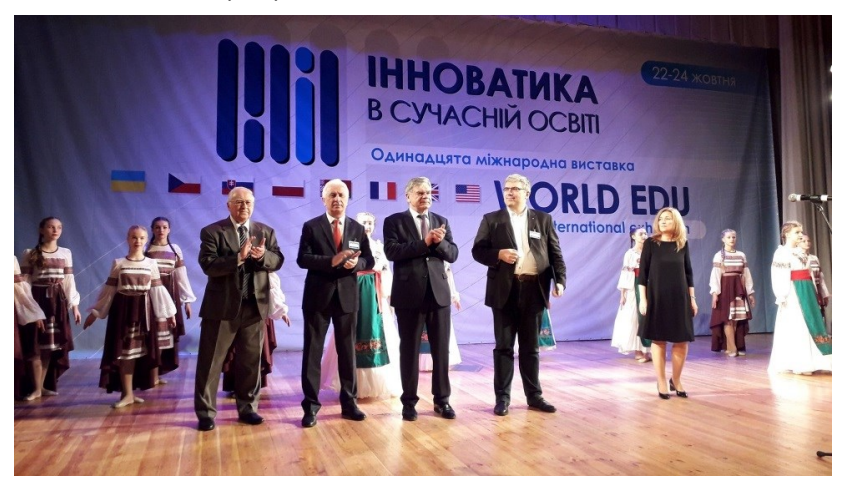

Загалом за участі фахівців МОН України, педагогічних, науково-педагогічних і наукових працівників наукових установ та закладів освіти, з якими тісно співпрацюють вчені НАПН України, щороку проводиться понад 500 науковопрактичних конференцій, семінарів, круглих столів та інших заходів з актуальних проблем модернізації освіти.

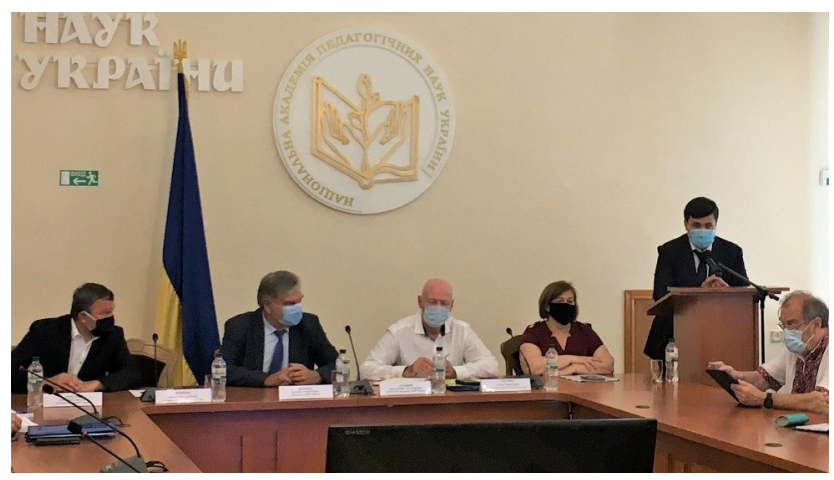

Провідні вчені НАПН України систематично беруть участь у роботі Колегії МОН України, щорічних серпневих конференцій, нарад. Натомість фахівці структурних підрозділів МОН України є постійними учасниками загальних зборів та методологічних семінарів, засідань Президії НАПН України тощо.

Аналіз результатів виконання Програми спільної діяльності МОН України та НАПН України на 2017-2020 роки засвідчує, що співпраця між вченим НАПН України і фахівцями МОН України відповідно до визначених у Програмі пріоритетних напрямів була ефективною, заплановані у Програмі заходи в основному виконано.

Водночас існує низка питань, що потребують подальшого вирішення в рамках спільної діяльності стосовно усіх ланок освіти (дошкільної, початкової, базової і профільної середньої, позашкільної освіти, освіти дітей з особливими потребами, професійної (професійно-технічної), фахової передвищої, вищої освіти, освіти дорослих), зокрема:

1. Реалізація ключових цілей та завдань Міністерства освіти і науки України:

- реформування дошкільної освіти та забезпечення наступності між дошкільною та початковою освітою шляхом ухвалення Базового компоненту дошкільної освіти;

- затвердження положення про дистанційну форму здобуття загальної середньої освіти, в якому буде передбачено доступність шкільної освіти в умовах карантинних обмежень незалежно від місця проживання здобувачів освіти; 
- упровадження педагогічної інтернатури для забезпечення наставництва та підтримки молодих вчителів;

- упровадження особистісно орієнтованої моделі освіти для осіб з особливими освітніми потребами;

- реалізація пілотного проєкту сертифікації педагогічних працівників тощо (МОН України, 2020c).

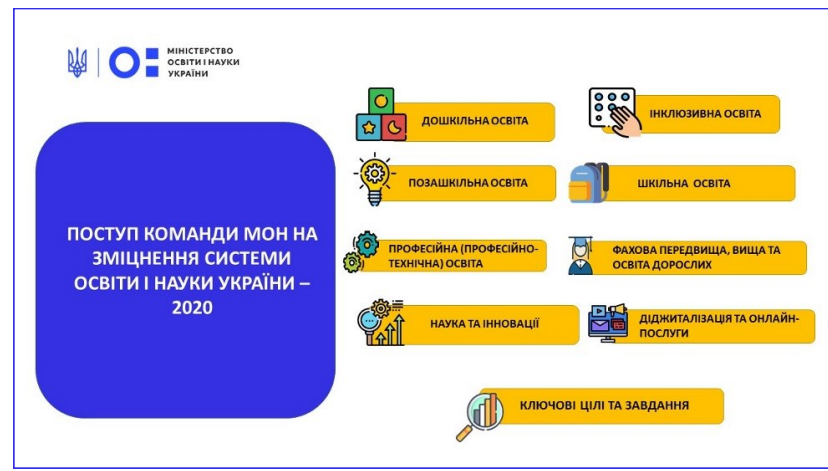

2. Співпраця щодо розв'язання загальних проблем розвитку освітньої сфери:

- розроблення й удосконалення законодавчих і нормативно-правових актів, спрямованих на реформування освіти і науки відповідно до актуальних вимог;

- розширення співпраці у спільних робочих групах з розроблення концептуальних документів у галузі освіти і науки;

- ширше залучення потенціалу вчених НАПН України до створення стандартів освіти, навчальних програм, фахової експертизи навчальних і навчально-методичних видань;

- своєчасне видання і поширення навчальної літератури для учнів та навчально-методичної літератури для педагогів з метою оптимізації освітнього процесу в умовах Нової української школи, удосконалення науково-методичного забезпечення професійної підготовки / підвищення кваліфікації педагогів Нової української школи;

- прийняття Стратегії розвитку професійної (професійно-технічної) освіти на період до 2023 року;

- розроблення методики оцінювання готовності педагогічних працівників закладів професійної (професійно-технічної) освіти та наставників підприємств до професійної підготовки майбутніх кваліфікованих робітників за дуальною формою здобуття освіти. Розроблення проєкту Положення про організацію взаємодії публічно-приватного партнерства у сфері професійної освіти;
- прийняття Стратегії розвитку вищої освіти в Україні на 2021-2031 рр.;

- запровадження та моніторинг КPI у діяльність закладів вищої освіти для оцінювання ефективності управління;

- розроблення проєкту Стратегії освіти впродовж життя в Україні на 2020-2030 рр.;

- удосконалення процедури провадження експериментальної роботи всеукраїнського рівня;

- удосконалення науково-методичних та правових засад здійснення психологічного супроводу суб'єктів освітньої діяльності та надання їм психологічної допомоги у дистанційному та комбінованому форматі;

- створення дорадчого органу або координаційної ради психологічної служби системи освіти;

- забезпечення наявності у структурі $\mathrm{MOH}$ України підрозділу з вирішення питань діяльності та інноваційного розвитку бібліотек освітянської галузі та ін.

\section{СПИСОК ВИКОРИСТАНИХ ДЖЕРЕЛ}

Вісник Національної академії педагогічних наук України. (2019-2020). Архів. https://visnyk.naps.gov.ua/ index.php/journal/issue/archive

Електронна бібліотека Національної академії педагогічних наук України. (n.d.). Головна. https://lib.iitta.gov.ua/

Кремень, В.Г. (ред.). (2018). Звіт про діяльність Національної академії педагогічних наук України в 2017 p. Київ: НАПН України. https://bit.ly/3fOWzsk

Кремень, В.Г. (ред.). (2019). Звіт про діяльність Національної академії педагогічних наук України у 2018 р. Київ: НАПН України. https://bit.ly/2XRqrgl

Кремень, В.Г. (ред.). (2020). Звіт про діяльність Національної академії педагогічних наук України у 2019 р. Київ: НАПН України. https://bit.ly/3cVbbn7

Міністерство освіти і науки України. (2020а). Громадські обговорення 2020. https://cutt.ly/8haBDzC

Міністерство освіти і науки України. (2020b, 18 листопада). Очільник МОН Сергій Шкарлет обговорив питання співпраці з членами Президії Національної академії педагогічних наук. https://cutt.ly/ khaB61B

Міністерство освіти і науки України. (2020с, 15 жовтня). Поступ команди МОН на зміцнення системи освіти і науки України. https://mon.gov.ua/ua/ news/postup-komandi-mon-na-zmicnennya-sistemiosviti-i-nauki-ukrayini

Національна академія педагогічних наук України. (n.d.). Головна. http://naps.gov.ua/

Національна академія педагогічних наук України. (n.d.). Головна [Facebook page]. Facebook. https:// www.facebook.com/ua.naps

Національна академія педагогічних наук України. (2017). Програма спільної діяльності Міністерства освіти і науки України та Національної академії педагогічних наук України на 2017-2020 роки. http://naps.gov.ua/ua/activities/research/mon/ 


\section{ON PERFORMING THE JOINT ACTIVITY PROGRAM OF THE MINISTRY OF EDUCATION AND SCIENCE OF UKRAINE AND NATIONAL ACADEMY OF EDUCATIONAL SCIENCES OF UKRAINE FOR 2017-2020 \\ Scientific report at the meeting of the Presidium of the National Academy of \\ Educational Sciences of Ukraine, November 18, 2020 \\ Vasyl Kremen \\ DSc in Philosophy, Professor, Full Member (Academician) of NAS of Ukraine and NAES of Ukraine, President, National Academy of Educational Sciences of Ukraine, Kyiv, Ukraine Volodymyr Lugovyi \\ DSc in Education, Professor, Full Member (Academician) of NAES of Ukraine, First Vice-President, National Academy of Educational Sciences of Ukraine, Kyiv, Ukraine Oleh Topuzov \\ DSc in Education, Professor, Full Member (Academician) of NAES of Ukraine, Vice-President, National Academy of Educational Sciences of Ukraine, Kyiv, Ukraine Iryna Reheilo \\ DSc in Education, Senior Researcher, Head of the Scientific and Organizational Department, National Academy of Educational Sciences of Ukraine, Kyiv, Ukraine Nataliia Bazeliuk \\ PhD in Education, Deputy Head of the Scientific and Organizational Department, National Academy of Educational Sciences of Ukraine, Kyiv, Ukraine}

Abstract. The information on performing the Joint Activity Program of the Ministry of Education and Science of Ukraine and National Academy of Educational Sciences of Ukraine for 2017-2020 is presented. The following actions were carried out: improvement of the Ukrainian legislation, development of conceptual and regulative documents in the sphere of education; scientific and methodological support of the all-Ukrainian experiments; development of the training and methodological assurance for the New Ukrainian School, in particular for children with special needs; psychological and pedagogical expertise of training, training and methodological literature, teaching aids and training equipment; in-service teacher training; participation in the expert, working groups and commissions of the MoES of Ukraine; conducting joint scientific and practical events, etc. The issues that need further solution in a joint activity for all levels of education (preschool, primary, basic and profile secondary, out-of-school education, education of children with special needs, vocational, professional pre-higher, higher and adult education) are outlined.

Keywords: Joint Activity Program; Ministry of Education and Science of Ukraine; National Academy of Educational Sciences of Ukraine; science; education; pedagogy; psychology; scientific and methodological support of education; innovative person development. 